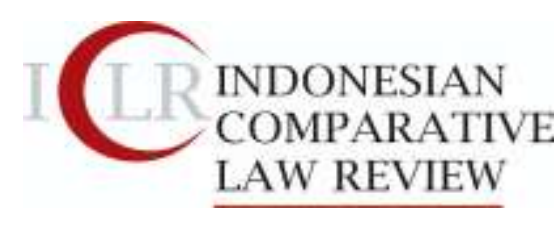

Volume 1 No 2, June 2019

P-ISSN: 2655-2353, E-ISSN: 2655-6545

\author{
Article Info: \\ Received : $03-07-2019$ \\ Revised : $02-08-2019$ \\ Accepted : $20-08-2019$ \\ http://dx.doi.org/10.18196/iclr.1209

\section{Facing The Industrial Revolution 4.0: Taiwanese And Indonesian Perspective} \\ Try Hardyanthi ${ }^{1}$, Falah Al Ghozali ${ }^{2}$, Muhammad \\ Arizka Wahyu ${ }^{3}$ \\ 1,2,3Financial and Economic Law Department, Asia University, Taiwan \\ E-mail:1tryhardyanthi@gmail.com; \\ 2falahalghozali@windowslive.com; \\ 3muhammad.arizkawahyu@gmail.com
}

\begin{abstract}
Industrial Revolution 4.0 offers both challenges and opportunities for all countries. Every country has to adopt best strategies to deal with its dynamic and complexity. This paper aims at discussing the legal policies adopted by Indonesia and Taiwan to face this industrial revolution. This research employs a descriptivequalitative method with comparative approach. It is found that Industrial
\end{abstract}

robots and production lines, the automation of manufacturing Rrevolution 4.0, also known as the intelligent industry, seeks to transform a company into an intelligent organization to achieve the best business results. Indonesia officially launched the road-map called "Making Indonesia 4.0" in 2018. In the same year, Indonesia has started to set up the main plain of the program for five focuses sectors ex: food and drink, textile and clothing, automotive, chemist and electronic, and additional ten cross priority sectors. While Taiwan proposed its own version of Industry 4.0 called "Productivity 4.0" in 2014. This includes the use of large quantity of

\footnotetext{
${ }^{1}$ Vuksanović, Dragan \& Vešić, Jelena \& Korčok, Davor. (2016). Industry 4.0: the Future Concepts and New Visions of Factory of the Future Development. 293-298. 10.15308/Sinteza-2016-293-298.
}

The world around us has been changing on a daily basis along with development of human civilization. Therefore, technical and technological developments of production are changing as well. The Industrial Revolution 4.0 is a model that shows how industrial production follows the latest developments and changes over time. Thereby, the man, machine and the production itself constitute the force in one intelligent and independent network. ${ }^{1}$ Ateeq Khan and Klaus Turowski in their paper define Industry 4.0 as a revolution enabled by application of advanced technologies (like IT) at production level to bring new values and services for customers and organization itself. 
They will also bring flexibility and quality in production systems to fulfill demands of new innovative business models and services quickly (service-oriented architecture and network communication at production level). The digitalization and virtualization are tools to bring end to end services throughout a product life cycle (design till recycle) and in a cost-effective way for customers. ${ }^{2}$

The Industrial Revolution 4.0 is the subset of the fourth industrial revolution that concerns industry. The fourth industrial revolution encompasses areas which are not normally classified as industry, such as smart cities for instance. It refers to a new phase in the Industrial Revolution that focuses heavily on interconnectivity, automation, machine learning, and real-time data. Industry 4.0, also sometimes referred to as IIoT or smart manufacturing, marries physical production and operations with smart digital technology, machine learning, and big data to create a more holistic and better-connected ecosystem for companies that focus on manufacturing and supply chain management. ${ }^{3}$

The Industrial Revolution 4.0 fosters what has been called a "smart factory". Within modular structured smart factories, cyberphysical systems monitor physical processes, create a virtual copy of the physical world and make decentralized decisions. Over the Internet of Things, cyber-physical systems communicate and cooperate with each other and with humans in real-time both internally

\footnotetext{
2 Khan, A. and Turowski, K., A Perspective on Industry 4.0: From Challenges to Opportunities in Production Systems. In Proceedings of the International Conference on Internet of Things and Big Data (IoTBD 2016), pages 441-448, DOI: $10.5220 / 0005929704410448$

${ }^{3}$ What is Industry 4.0 - the Industrial Internet of Things (IIoT)? https:// www.epicor.com/enus/resource-center/articles/what-is-industry-4-0/ accessed on August 28, 2019
}

and across organizational services offered and used by participants of the value chain. ${ }^{4}$ The Industrial Revolution 4.0 has the potential to help companies meet the current challenges of industrial value creation. Thus, Industry 4.0 can help companies adequately meet the increasing volatility of the markets, the increasing demands and complexity of products and services, as well as the shortening of innovation cycles. The first generation of the industrial revolution is characterized by the use of steam engines to replace human and animal power. The second generation is distinguished by the application of mass production concept and the beginning of electric power utilization.

The third generation is marked by the use of automation technology in industrial activities. Indonesia has been entering the new era of Industry 4.0 which marked by the increasing connectivity, interaction, as well as more convergent people, machines and other resources as the result of information and communication technology advancement. ${ }^{5}$ To achieve the objective to get into the Top 10 Global Economy, Making Indonesia 4.0 states the commitment of the country to build a strong manufacturing industry in 2030: To double the productivity to cost ratio, to increase export to $10 \%$ of the GDP, and to allocate $2 \%$ of GDP for technology research and development. The roadmap of Making Indonesia 4.0 consists of

4 Hermann, Pentek, Otto, 2016: Design Principles for Industrie $\quad 4.0 \quad$ Scenarios, available at https://pdfs.semanticscholar.org/069c/d102faebef48f bb7b531311e0127652d926e.pdf, accessed on September $4^{\text {th }}, 2019$ at 12.23 a.m.

${ }^{5}$ Making Indonesia 4.0: Indonesia's Strategy to Enter the 4th Generation of Industry Revolution https://www.investindonesia.go.id/en/whyinvest/indonesia-economic-update/makingindonesia-4.0-indonesias-strategy-to-enter-the-4thgeneration-of-ind accessed on August 31, 2019 at 4.59 p.m. 
5 (five) priority industrial sectors with 10 (ten) national priority to strengthen the industrial structure in Indonesia. ${ }^{6}$

National priority number 3 declares that Indonesia will accommodate the standards in sustainability, also including energy consumption in industrial sectors. Strategies and goals are set to be achieved in 2030 in each industry sectors priority: food and beverages, chemical, textile, automotive, and electronics. In Taiwan, government is committed to promoting the smart machinery industry with the aim of making Taiwan a global manufacturing hub for intelligent machinery. Industry 4.0, or the fourth industrial revolution, refers to an industrial transformation aided by smart manufacturing and data exchange, such as high-level factory automation and Internet of Things applications.

\section{Taiwanese and Indonesian Perspective on the Industrial Revolution 4.0}

\subsection{Taiwan Productivity 4.0 Initiative in} the Republic of China

In the second decade of the 21st century, rapid proliferation of technology and intensified global competition have created a sense of urgency for governments of developed and developing nations alike to engage in major industrial revitalization, leading to global emergence of something generically known of as Industry 4.0, with a core of industrial transformation, revitalization and development. Industry Concept 4.0 originated from the Hannover Industrial Fair in 2011, with a view to

\footnotetext{
${ }^{6}$ Ministry of Industry of Republic of Indonesia, 2018, "Making Indonesia 4.0," available at https://www.kemenperin.go.id/download/18384, downloaded on August 16 ${ }^{\text {th }}, 2019$, at 1.43 a.m.
}

increasing German manufacturing levels through the adoption of new technologies such as the Internet of Things. In 2013, the United Nations Industrial Development Organization (UNIDO) and the Manufacturing Research Institute of the University of Cambridge reported, "Emerging trends in the global manufacturing industry" indicate that the future of global manufacturing will face major challenges.

The economic development and the number of industries in Taiwan that are very advanced and can reach the international market make Taiwan No.1 and get a lot of foreign exchange. Based on Taiwan's unique industrialization process, critical role in the global commodity chain and technical advantages, the tennis racket, footwear, textile, bicycle and personal computer manufacturing industries have been chosen to showcase the unique entrepreneurial and fighting spirits of the Taiwanese. Taiwan, with its position as a manufacturing powerhouse among the Asia production and supply chain, has long been an important partner for globally renowned brands. Germany has long touted "Industry 4.0 " at the helm of its economic initiatives, and they have realized that the factory size most suited for this new industry era is not the super factories of more than a hundred thousand employees, but their mid-to -small sized counterparts. In the past, these mid-tosmall sized companies have been pillaring of strength in Taiwan's economic miracle.

In 2014, comprised over 50\% of machinery and electronics of Taiwan's total exports and brought around USD 154.9 billion into Taiwan local economy. Taiwan is a leading producer of semiconductors, solar 
cells, display screens, motherboards, and other mid-stream components, and companies based in Taiwan assemble much of the world's finished tech products at manufacturing sites in China. In particular, industry insiders are highly optimistic that the burgeoning Internet of Things (IoT), along with advances in 3D printing, will provide opportunities not only for hardware manufacturing but also for the hardware makers to team up with service providers or become service providers themselves to provide integrated solutions. The IoT refers to technologies that enable appliances, devices, and even automobiles to communicate and react independently, providing increasing convenience and comfort for consumers. Points to Taiwan's technological capabilities in integrated sensors, actuators and other computing hardware all vital to the IoT as examples of the Taiwan's advantages in entering this sector.

The Taiwan government is promoting movement in this direction under the policy umbrella it is calling Productivity 4.0, inaugurated this past spring and based on the international concept of Industry 4.0. Conceived in Germany in 2011, Industry 4.0 refers to the "fourth industrial revolution" (following the first three of steam power, electrical power, and industrial automation) in which the digitization of industry is extended into the Internet. The concept foretells a future in which humans and machines communicate in real time across the entire value chain via IoT, enabling highly flexible, highly customizable "smart" manufacturing. This program has the aim of promoting the application of smart technology to enhance the transformation of industries into modern ones such as agriculture, textiles, 3C (computers, communications and consumer electronics), health, transportation, logistics and metal management. Government and industry leaders in Taiwan recognize the potential significance of Industry 4.0 in raising productivity have taken the vision even further in the new industrial policy.

There are six steps in building the Taiwan Productivity 4.0 plan. First, optimizing the smart supply chain ecosystem in the critical leading industries. Second, fostering new ventures; the movement of new ventures and startups is strong and prosperous in Taiwan. However, incubating and accelerating the new ventures in CPS-related areas, solution services, materials, medical, and smart manufacturing could facilitate sustainable competence-building. Third, promoting those local contents with competitiveness, such as critical components, systems, or services, will help enhance their capabilities of Productivity 4.0. The fourth step will be obtaining self-development and gamechanging technology capabilities. Cultivating experiences and talents through industrial-academic-institute cooperation, interdisciplinary learning, and international linking to build up their own competitiveness will be the fifth step. The last step is to support industry development and lead enterprise proliferation by the necessary industry policy tools to complete the whole ecosystem.

The stated goal of Productivity 4.0 is to increase competitiveness not only in manufacturing but also in the service and agricultural sectors by using the tools and concepts provided by the IoT, Big Data, and automatic systems like smart robotics. 
Stephen $\mathrm{Su}$ is general director of the Industrial Economics and Knowledge Center (IEK) under Industrial Technology Research Institute (ITRI) notes that key aspects of Productivity 4.0 include flexible value chains with information available in real time across companies, plus decentralization of modular production units. These "cyberphysical systems" networks of intelligent, connected equipment would be able to make independent decisions, thereby increasing efficiency, adaptability, and reliability through the entire process.

For the industrial sector, Taiwan has its own law that is Statute for Industrial Innovation, amended on July 24th, 2019 regarding on the furtherance of industrial innovation, improvement of the industrial environment, and enhancement of industrial competitiveness. The term "industries" as used in this Statute shall refer to agricultural, industrial, and service businesses. In Taiwan, basically, the policy dimension focuses on three points, among which are, first the 'Environmental Side' this dimension is the most attracts attention. Second is the 'Demand Side' policy, and Third the 'Supply Side' considered less important. However, Taiwan tends to focus more on environmental side policies because the superiority of industrial competition can be increased through improving the industrial environment. This policy tool will help developing industrial innovation and the domestic market environment by allocating financial resources and developing political support for the industrial structure. Therefore, for Taiwanese Government, the policy focus has been placed on the environmental side policy that needed infrastructure by developing Industrial Revolution 4.0. Taiwan favors distributing resources which are only into all these three policy categories should be expanded with any specificity of industrial type.

\subsection{Making 4.0 in the Republic of Indonesia}

Explaining the industrial revolution is a long-standing problem in social science, and all manner of prior events have been adduced as causes. The role of political structure; parliamentary checks on the executive, the security of property rights, the flexibility of the legal system; is at the center of much current discussion. In Indonesia, the development of Industry 4.0 was strongly encouraged by the Ministry of Industry. Its Minister, Airlangga Hartarto, said that for Indonesia to compete with other countries in the industry, Indonesia must also follow the trend. He further explained that the Industry 4.0 is a transformation effort towards improvement by integrating the online world and production lines in the industry, where all production processes run with the internet as the main support.

Industry 4.0 initiative is the global trend in the manufacturing industry. The implementation of Industry 4.0 aims to achieve the great national aspirations, which are bringing Indonesia upward to reach 10 biggest economies by 2030, returning the industry net export rate to 10 percent, doubling the labor productivity rate over the labor costs, and allocating $2 \%$ of Gross Domestic Product (GDP) to research and development (R\&D) and technology innovation fields (or 7 times higher than current allocation). To reach this, Indonesian government has formulated ten national priority strategies as follow: reforming the flow of materials, industrial zone redesign, improvement of human resources quality, 
empowerment of Micro Small and Medium Enterprise (UMKM), incentives implementation on technology investment, formation of innovation ecosystem, attracting foreign direct investment, harmonization of policy and regulations, building the national digital infrastructure, and accommodating sustainability standard.

Secretary-General of the Ministry of Industry, Haris Munandar, on the same occasion also revealed that one of Indonesia's strategies to enter Industry 4.0 is preparing five manufacturing sectors to become pilot in strengthening the fundamental structure of the national industry. The five sectors namely Food and Beverage Industry, Automotive Industry, Electronic Industry, Chemical Industry, and Textile Industry.

There are some measures and initiatives by the Indonesian government which aim to speed up the implementation of industry 4.0. These include funding and subsidies, as well as tax holiday programs. To ensure maximum impact by the roadmap, a wide range of stakeholders are being involved. Leading industry companies, industry associations, tech companies, as well as research and educational organizations are some of the stakeholders being engaged by the government.

As a first step, the government has established a committee with responsibility for the implementation of the different measures in the roadmap. Furthermore, it has been tasked with designing a program for quick wins. The committee consists of several representatives from various government departments, such as ministry of finance, and ministry of trade, but also ministry of energy, and ministry of technology, to name a few. Additionally, members of the Indonesian Chamber of Commerce and Industry (KADIN) as well as the Indonesian Investment Coordinating Board (BKPM) are represented.

The government might have taken the leap to compete in the new industrial revolution. However, Indonesia was not fully independent to start the fourth industrial revolution due to four major challenges. First and second are capability and funding problems. According to Indonesian Food and Beverage Producers Association (GAPMI) Chairman, Adhi S. Lukman, in order to fully implement Industry 4.0, the manufacturing sectors need not only huge fresh funds, but also foreign talent to help upgrade the quality and capability of domestic industry, as most Indonesian manufacturers had just shifted to Industry 3.0.

Third, the lack of technology and system suppliers capable of Industry 4.0, where artificial intelligence (AI) and Big Data are required, in Indonesia has discouraged domestic industry from migrating quickly. Fourth, the overlapping of regulations and policies require synchronization or harmonization. The problem has yet to be fully solved under the President Joko Widodo-Vice President Jusuf Kalla administration.

Since Indonesia is the rule of law state as stated in the 1945 Constitution of the Republic of Indonesia that the State of Indonesia shall be a state based on the rule of law, therefore every state action has to be in the basis of law. The question may arise is whether Indonesia has its own national law regarding the Industry 4.0. A simple 
question yet must be considered deeply by the government as the policy maker in the country.

The existence of law related to Industry 4.0 is important to regulate the standards used for companies especially if for example Indonesia really wants to use robots to later do the human jobs. If the robots conduct the wrong-doing actions and it violates the laws of the nation, then who will be responsible for the actions? It seems impossible to put the responsibility on the robots. Are the robot makers, government, or company liable for the actions the robots do? Those things are only a piece of doubt to face the new revolution of Industry.

Another challenge for the country is that the industrial revolution and global economy will drive for corporate competitiveness and flexibility has led to sweeping changes in the ways enterprises are organized, economically, financially and in terms of their workforce. Developments such as the emergence of global financial networks, outsourcing, relocation and the establishment of networks of enterprises have had far-reaching consequences for labor relations and labor law enforcement. It indeed must be taken a consideration to finally implement the Industry 4.0 in the country.

A fresh air for the industrial sector in the country is that the government released the direction of the national industrial strategy, specifically in facing the Industry 4.0 , which is the main focus is on the food and beverage, electronics, automotive, textile and chemical industries as well as the 10 New Bali or 10 Bali Baru. On Friday, February 2nd, 2018 in Jakarta, Indonesian President, Joko Widodo, enacted the
Presidential Decree Number 2 Year 2018 concerning the National Industrial Policy 2015-2019. The Decree set about important plans in industrial field, namely, industrial development goals, focus on industrial development, stages of the achievement of industrial development, industrial resource development, development of industrial facilities and infrastructure, industrial empowerment, development of priority industries and small industries and mediumsized industries, industrial regional development, and fiscal and non-fiscal facilities.

President Joko Widodo administration has planned the direction of industrial sector in really great framework. However, the Industry 4.0 which focuses on the internet and the development of the information technology will absolutely lead to the openness on everything. The society seems to use it for both positive and negative activities. The government must take actions in handling the negative side of the internet and information technology. Moreover, Prof. Dr. John Pieris, S.H., M.S., a lecturer in the Postgraduate Program of Universitas Kristen Indonesia in Jakarta, believed that the Industrial Revolution 4.0 with its main knot that is the internet and information technology triggering changes in the mindset, work patterns, and lifestyle of citizens in various countries. He further stated that humans must remain positioned as the subject of a new civilization based on the Industry 4.0; the choice in the field of law is to maintain the basic principles of the law of the Republic of Indonesia and on the other hand formulate the flexible regulations and policies to respond to new changes in society and the environment. 
At the end, as the opportunities and the challenges of the Industry 4.0 for Indonesia, it leads a lot of debate and discussion among the experts, governments, and society. What if the Industry 4.0 fails to take a root? Therefore, Joko Widodo administration does not need to be rash to follow the new trend of industrial sector. The decision to adopt the industrial revolution should be built upon a really deep consideration, including the scrutiny of politics, economic, and legal aspect.

\section{Conclusion}

Industrial Revolution 4.0 offers both challenges and opportunities for all countries. Every country has to adopt best strategies to deal with its dynamic and complexity. The economic development and the number of industries in Taiwan that are very advanced and can reach the international market make Taiwan No.1 and get a lot of foreign exchange. Adequate expertise in sophisticated machinery development, and information and communications technology are two fields that are among Taiwan's greatest strengths which made the success in Industry 4.0. Aside of that, Taiwan already has its own law that is Statute for Industrial Innovation regarding on the furtherance of industrial innovation, improvement of the industrial environment, and enhancement of industrial competitiveness. The term "industries" as used in this Statute shall refer to agricultural, industrial, and service businesses. The policy dimension focuses on three points, among which are, the Environmental Side, Demand Side and Supply Side.
The Republic of Indonesia is optimistic that this is an opportunity for Indonesia to create more jobs and join the top ten largest economies in the world by 2030. The government has published a roadmap containing ten strategic steps to anticipate this revolution, including boosting vocational education. The aims of Industrial 4.0 programs to help the country better compete in the global market in the digital era, create more jobs and become among the top ten largest economies in the world by 2030. Nevertheless, the country should realize that there are some challenges present for Industry 4.0 in Indonesia including the capability issues, funding problems, lack of technology/digital infrastructure and system suppliers for Industry 4.0, and the regulation and policy overlaps that require further synchronization. Indonesia is the rule of law state as stated in the 1945 Constitution of the Republic of Indonesia that the State of Indonesia shall be a state based on the rule of law. Therefore, every state action has to be in the basis of law. The existence of law and regulation related to Industry 4.0 is crucially important to regulate the standards used for companies particularly if for example Indonesia really wants to use robots to later do the human jobs.

\section{References}

Book

Chu-Chi Kuo, et. al, 2019, "Industrial Revitalization Via Industry 4.0 - A Comparative Policy Analysis among China, Germany and the USA", Global Transitions, December $2^{\text {th }}, 2018$, KeAi Chinese Roots Global Impact.

Khan, A. and Turowski, K., A Perspective on Industry 4.0: From Challenges to Opportunities in Production Systems. In Proceedings of the International Conference on Internet of Things 
and Big Data (IoTBD 2016), pages 441-448, DOI:

10.5220/0005929704410448

Marie-Laure Morin, 2005, “Labour Law and New Forms of Corporate Organization", International Labour Review, Vol. 144 No. 1, 2005, International Labour Organization.

Ministry of Industry of the Republic of Indonesia, 2018, Making Indonesia 4.0: Indonesia's Fourth Industrial Revolution, July 24 - 27, 2018, Jakarta, Kementerian Perindustrian Republik Indonesia.

Robert C. Allen, 2006, Explaining the British Industrial Revolution from the Perspective of Global Wage and Price History, United Kingdom, Oxford University.

Yonglin Liao, et. al, 2017, "The Impact of the Fourth Industrial Revolution: A Cross-Country/Region Comparison", Production, November 22 ${ }^{\text {nd }}, 2017$, ISSN 1980-5411 (On-line version).

\section{Journal}

Lin, Kuan Chung, et. al., 2017, “A Cross-Strait Comparison of Innovation Policy under Industry 4.0 and Sustainability Development Transition", Journal of Sustainability, May 2017, doi:10.3390/su9050786.

Vuksanović, Dragan \& Vešić, Jelena \& Korčok, Davor. (2016). Industry 4.0: The Future Concepts and New Visions of Factory of the Future Development. 293-298. 10.15308/Sinteza-2016293-298.

\section{Internet}

Business Sweden, 2019, “Industry 4.0 in Indonesia: Market Opportunities, Future Trends and Challenges", taken from https://www.businesssweden.se/globalassets/indonesia-industry-

4.0.pdf, downloaded on Tuesday, September 3, 2019 , at 2.23 p.m.

Digital Taiwan - Culture \& Nature, "History of Industrial Development in Taiwan", available at http://culture.teldap.tw/culture/index.php?opti on=com_content\&view=article\&id=1358:historyof-industrial-development-in-taiwan-parti\&catid=156:lives-and-cultures, accessed on August 17th, 2019 at 1.56 a.m.

Fens Alwino, 2019, “Kecerdasan Hukum Respons Revolusi Industri 4.0", taken from http:/ / staging-
point.com/read/2018/11/14/151205/Kecerdasa

n.Hukum.Respons.Revolusi.Industri.4.0., accessed on Wednesday, September 4, 2019, at 8.43 p.m.

Hermann, Pentek, Otto, 2016: Design Principles for Industrie 4.0 Scenarios, available at https://pdfs.semanticscholar.org/069c/d102faeb ef48fbb7b531311e0127652d926e.pdf, accessed on September 4th, 2019 at 12.23 a.m.

Indonesia Investment Coordinating Board, 2019, “Making Indonesia 4.0: Indonesia's Strategy to Enter the 4th Generation of Industry Revolution", taken from https://www.investindonesia.go.id/en/whyinvest/indonesia-economic-update/makingindonesia-4.0-indonesias-strategy-to-enter-the4th-generation-of-ind, accessed on Tuesday, September 3, 2019, at 2.02 p.m.

Making Indonesia 4.0: Indonesia's Strategy to Enter the 4th Generation of Industry Revolution https://www.investindonesia.go.id/en/whyinvest/indonesia-economic-update/makingindonesia-4.0-indonesias-strategy-to-enter-the4th-generation-of-ind accessed on August 31, 2019, at 4.59 p.m.

The Ministry of Industry of Republic of Indonesia, 2018, "Making Indonesia 4.0," available at https://www.kemenperin.go.id/download/1838 4, downloaded on August 16th, 2019, at 1.43 a.m.

Nur Chandra Laksana, 2019, “Apa itu Industri 4.0 dan Bagaimana Indonesia Menyongsongnya", taken from https://www.tek.id/tek/apa-itu-industri4-0-dan-bagaimana-indonesia-menyongsongnyab1Xb19d4L, accessed on Tuesday, September 3, 2019, at 1.44 p.m.

Tenggara Strategics, 2019, “The Challenges for Industry $4.0^{\prime \prime}, \quad$ taken from https://tenggara.id/media/The-challenges-forIndustry-40, accessed on Tuesday, September 3, 2019, at 3.03 p.m.

Timothy Ferry, "Taiwan Aiming for Industrial Transformation", available at https:/ / topics.amcham.com.tw/2015/08/taiwan -aiming-for-industrial-transformation/, accessed on August 31st, 2019 at 12.31 p.m.

What is Industry 4.0 - the Industrial Internet of Things (IIoT)? https://www.epicor.com/en- 
102

Indonesian Comparative Law Review

us/resource-center/articles/what-is-industry-4-

0/ accessed on August 28th, 2019 at 9.12 a.m.

\section{Regulation}

The 1945 Constitution of the Republic of Indonesia.

Republic of China' Statute for Industrial Innovation.

Presidential Decree Number 2, year 2018 on the National Industrial Policy 2015-2019. 